\title{
Modularisation strategies in the AEC industry: a comparative analysis
}

Shafiee, Sara; Piroozfar, Poorang; Hvam, Lars; Farr, Eric R.P.; Huang, George Q.; Pan, Wei; Kudsk, Anders; Rasmussen, Jeppe Bredahl; Korell, Manuel

Published in:

Architectural Engineering and Design Management

Link to article, DOI:

$10.1080 / 17452007.2020 .1735291$

Publication date:

2020

Document Version

Peer reviewed version

Link back to DTU Orbit

Citation (APA):

Shafiee, S., Piroozfar, P., Hvam, L., Farr, E. R. P., Huang, G. Q., Pan, W., Kudsk, A., Rasmussen, J. B., \& Korell, M. (2020). Modularisation strategies in the AEC industry: a comparative analysis. Architectural

Engineering and Design Management, 16(4), 270-292 . https://doi.org/10.1080/17452007.2020.1735291

\section{General rights}

Copyright and moral rights for the publications made accessible in the public portal are retained by the authors and/or other copyright owners and it is a condition of accessing publications that users recognise and abide by the legal requirements associated with these rights.

- Users may download and print one copy of any publication from the public portal for the purpose of private study or research.

- You may not further distribute the material or use it for any profit-making activity or commercial gain

- You may freely distribute the URL identifying the publication in the public portal 


\title{
Modularisation Strategies in the AEC Industry: A Comparative Analysis
}

\begin{abstract}
Many industries have benefited from modularisation; while in the architecture, engineering and construction (AEC) industry, the concept of modularisation is associated with dimensional coordination. This has added to an already extensive list of challenges due to market size and the concept of economies of scale in AEC industry, to name but a few. Moreover, there is a myth that the AEC industry is bound to stay associated with build-to-order or made-to-order approach caused the AEC industry to restrict modularisation to the component level. This changes the balance in favour of what this paper calls a bottom-up approach. On the other hand, a valid alternative strategy - referred to in this study as top-down strategy - remains very much underexploited. The clients, therefore, do not have a neutral means by which they can assess which strategy is in their best interest. Likewise, if a construction company plans to make a strategic move towards the principles of modularisation and off-site manufacturing, they do not have clear decision support tool. This study investigates these two main modularisation strategies in the AEC industry to provide some examples of successful cases regarding how, when and where such strategy have been applied by different construction companies in different cases. The collected and collated empirical data and the results from the interviews will help clients and companies to analyse their own cases and make operational decisions on how, when and where to best utilise the bottom-up and top-down modularisation techniques while considering the pros and cons of such decisions.
\end{abstract}

Keywords: modularisation; architecture, architecture, engineering and construction (AEC); top-down modularisation; bottom-up modularisation; industrialised building systems 


\section{Introduction}

Some manufacturing industries have achieved significant advances in efficiency by offering customised products (Hvam, Mortensen, \& Riis, 2008). These industries standardise product alternatives to facilitate the sales and production processes (Alexander Felfernig, Reiterer, Reinfrank, Ninaus, \& Jeran, 2014) by incorporating information about product features, product structure, production processes, costs and prices (Forza \& Salvador, 2006). A building is seen as a set of major building component systems, such as walls, roofs and foundations, and enterprises within off-site production and on-site assembly of products and components mutually contribute to the AEC project (Lachimpadi, Pereira, Taha, \& Mokhtar, 2012). Compared to other industries, the architecture, engineering and construction (AEC) industry is often criticised for its inefficiency or inability to automate, improve its practices and provide value for its clients (Thuesen \& Hvam, 2013).

Some of the substantial challenges facing the AEC industry include market size, diversity of customers' needs, requirements and preferences and leveraging economies of scale for personalised end-products (Farr, Piroozfar, \& Robinson, 2014; Goulding \& Arif, 2013). To overcome the challenges in AEC industries, principles from mass customisation can be developed and implemented (Hvam et al., 2008). The principles of mass customisation enable companies to individualize the products using a standardised production process, thus keeping costs down while increasing quality and customer satisfaction (Kudsk, Hvam, Thuesen, Grønvold, \& Olsen, 2013). Therefore, a mass customisation strategy must not only fulfil a wide variety of customer needs and demands but also harvest the benefits of economies of scale.

The main step towards customisation in the AEC industry is the standardisation and modularisation of components, which in this context means transforming traditional craftsmanship production into a modularised system. Modularity is the design principle of having a complex system composed of smaller subsystems that can be managed independently while functioning together as a whole (Langlois, 2002). Modularity in AEC industry can reduce order lead time and still create variety with limited resources (Bekdik, Pörzgen, Bull, \& Thuesen, 2018; Kudsk, Hvam, et al., 2013; Sharifah-Akmam, Gajendran, Skitmore, \& Brewer, 2018). Modular coordination is a standardisation system based on the dimensional coordination system for for sizing building components, placing them within a reference system and arranging off-site fabrication (Lawson, Ogden, \& Goodier, 2014; Singh, Sawhney, \& Borrmann, 2015). A sustainability assessment of AEC modular projects helps to understand the wider benefits of modular systems (Lawson et al., 2014; Smith, 2011). Module computation requires some basic data, particularly the size, the pipeline characteristic, and the equipment data (Cigolini \& Castellano, 2002; Tatum, Vanegas, \& Williams, 1987).

When trying to understand a complex system or product, two different strategies are normally used, known as top-down and bottom-up strategies (Sun \& Zhang, 2004). Several researchers have described the modularisation and design process of the AEC industries as an intensive, complex process (Bekdik et al., 2018; Choo, Hammond, Tommelein, Austin, \& Ballard, 2004; Haas \& Fagerlund, 2002; Mancini, 2014; Sawhney \& Maheswari, 2013; Singh et al., 2015). Moreover, due to the complexity in the AEC industry and the huge investments and risks connected to an AEC project, few companies have been able to modularise entire constructions in one step (Bekdik et al., 2018; Kohler \& Hassler, 2002; Kudsk, Grønvold, Olsen, Hvam, \& Thuesen, 2013; Vernikos, Goodier, Nelson, \& Robery, 2013). An alternative to this one-step implementation is to gradually implement and modularise parts or segments of a construction. Apart from the modularisation tools and techniques, this gradual modularisation process can be approached in two main ways, either using a top-down or a bottom-up strategy (Kudsk, Grønvold, et al., 2013). The former strategy analyses a large-sized module, whereby the entire building is the product. The latter strategy modularises a smaller sub-part of the construction, turning the sub-part into the product. 
When using the top-down strategy, the entire system is divided into a few main components, which are subdivided further into smaller elements until a satisfactory understanding of the design and production process is obtained (Kudsk, Hvam, et al., 2013; Sun \& Zhang, 2004). For example, when using the top-down strategy for constructing a house, the workflow starts with the large elements (e.g., the whole building), paying little attention to the finer details. By contrast, the bottom-up modularisation strategy examines the smallest elements first and combines them into larger components or modules (Kohler \& Hassler, 2002; Kudsk, Hvam, et al., 2013; Sun \& Zhang, 2004) to form the final product, namely the building. An example of the bottom-up strategy is a detailed description of the lighting mechanism inside a house, which is catalogued and combined with other elements by the design or construction team to form mid-sized components. These mid-sized components are then combined to form the whole concept of the house. Top-down modularisation can be selected for the same lighting system to conceptually determine the large elements of the system, with no attention given to the details while considering the high level of interface modularising to the other parts of the building.

Despite various studies on modularisation and customisation in the AEC industry (Farr et al., 2014; Hartmann, Meerveld, Vossebeld, \& Adriaanse, 2012), some gaps in research remain, especially when it comes to support for product modularisation in order to facilitate the automation and digitisation processes in the AEC industry. Moreover, although previous research has addressed modularisation in general (Baldwin \& Clark, 2000; Kratochvíl \& Carson, 2005; Mäkipää et al., 2010), few studies have examined how, when and where the modularisation techniques should be applied in the AEC industry, and no study has used theoretical concepts to compare the pros and cons of the different modularisation strategies (Piran, Lacerda, Antunes, Viero, \& Dresch, 2016). As discussed earlier, regarding the specific modularisation methods and techniques, for example in the production of car, computer, aviation, ships, the gradual modularisation process can be divided into bottom-up and top-down strategies. However, there is no research comparing these two main strategies in order to offer guidance to AEC companies in determining how best to adopt or implement them while providing some theoretical, analytically developed underpinnings based on empirical lessons learned from real-world practices. Accordingly, we compared four case companies with top-down and bottom-up modularisation approaches. We investigated the background information for all the cases as well as how they implemented the approaches. Moreover, we studied the influences of different modularisation approaches on the 11 most important performance measurements and the respective pros and cons. This study builds upon the state-ofthe-art in top-down and bottom-up research in the construction industry and contributes to existing knowledge by (1) adding new dimensions which have not been explored previously to evaluate the top-down and bottomup modularisation strategies, (2) devising a context-specific tool based on the qualitative comparative analysis (QCA) method, and (3) reviewing and adopting the relevant performance indicators in the AEC industry to assess the top-down and bottom-up strategies against these indicators. Therefore, this paper aims to fill this gap by comparing the top-down and the bottom-up modularisation strategies in the AEC industry while critically reviewing the pros and cons associated with the said strategies. The results of this research can inform AEC companies about the benefits and risks of modularisation in a more detailed and pragmatic manner.

\section{Research design and methodology}

This study uses a mixed methodology with an overall inductive approach and aims to enhance the practical understanding of the bottom-up and top-down strategies in the AEC industry as theories. Choosing multiple cases and multiple units of analysis, we aim to contribute to the existing knowledge in the field by (1) adding new dimensions which have not been explored before to analyse the top-down and bottom-up modularisation strategies in the AEC industry, (2) utilising QCA as a method tailored to a specific research design developed in this study and (3) systematically reviewing and linking the performance indicators in the AEC industry to analyse the top-down and bottom-up modularisation strategies using QCA. The study employs a multiple case and multiple unit of analysis approach, which involves analysing various modularisation projects for different 
products and processes in different companies. The different data sources included reviews of projects, product or process documentations, interviews and participant observations which were analysed using the QCA of performance measures and indicators. The study focuses primarily on the practical implementation of the top-down and bottom-up strategies and discusses modularisation methods for platform design through the different stages of its research methodology design. Therefore, the research design of this study has several components, as briefly explained below.

\subsection{Case study research}

The well-established modularisation strategies in product design and manufacturing - top-down and bottomup - are investigated in the context of the AEC industry using the QCA method based on an exploratory case study research design (Oakley, 1999). According to Gummesson (2000), when collecting empirical data from large organisations, a qualitative approach provides a good opportunity to obtain a sufficient level of detailed information. Case study research enables comparisons of different theories and observations from empirical data (McCutcheon \& Meredith, 1993; Van de Ven, 1989) and has considerable advantages over the statistical methods (Finifter, 1993). However, it is important to take into account that "case studies, like experiments, are generalisable to theoretical propositions and not to populations or universes" (Yin, 2009, p. 38) because cases are not sampling units and should be treated as experiments (Tsang, 2013). Although there is no ideal number of cases, using between four and ten cases usually works out well (Eisenhardt, 1989). Typically, the primary sources of data in case study research are obtained through interviews and field invistigations; other sources of data include personal observations, informal conservations, attending meetings and reviewing archival sources (Karlosson, 2016).

\subsection{Qualitative comparative analysis (QCA)}

The data collected for this research was analysed using a QCA method. An established method in business, human behaviour and innovation management studies, QCA is an analysis technique which extracts logical conclusions from datasets, making it relevant and appropriate for this study. QCA uses logical inference rules to determine the inferences supported by the dataset. The classical 'compare-and-contrast' and 'lens' (or 'keyhole') comparison approaches are both constructed based on five pillars: frame of reference, grounds for comparison, thesis, organisational scheme and linkages (https://writingcenter.fas.harvard.edu/pages/howwrite-comparative-analysis). The primary reason for comparative analysis is to gain a better understanding of the causal processes involved in the production of an event, feature or relationship, typically by introducing (or increasing) variation in the explanatory variable or variables (Pickvance, 2005). While Tilly (1984) proposed a rather elaborate classification of comparative analyses (namely, individualising, universalising, variationfinding and encompassing), Pickvance (2005) argued that the first type of analysis is not itself a comparative analysis and that there is not enough distinction between the third and fourth types to make them two different categories. Therefore, he proposed that comparative analysis can be classified according to two global categories - one seeking to explain similar phenomena by similar features and the other aiming to elucidate different phenomena by different features - which, he argued, were too restrictive. Subsequently, he proposed two other possibilities: explaining similar phenomena by different features and explaining different phenomena by similar features. While abstraction is asserted to be a strategy only for creating similarities, it is not understood to be the only one. Also, Pickvance (2005) concludes by stating that, while, while comparative analysis needs to be distinguished from the juxtaposition of descriptions of a series of cases and separated from the sense in which all analysis is comparative, the two features which define comparative analysis are understood to be 1) an interest in the explanatory question of why the observed similarities and differences between cases exist and 2) the reliance on the collection of data on two or more cases, ideally according to a common framework. 
Consequently, this study uses a mixed QCA, classic compare-and-contrast approach which seeks to build upon all the possible observed similarities and differences (linkages) between two modularisation strategies (ground for comparison) in four selected case studies within the context of the AEC industry using performance measures and indicators (frame of reference) through a point-by-point comparison (organisational scheme). Our argument is that such an analysis will help clients, designers and companies to make informed decisions when choosing one strategy or the other or a combination of both (thesis).

\section{Literature review}

\subsection{Mass customisation}

The development of lean production led to the slow emergence of the paradigm of "mass customisation (Pine, 1993). Mass customisation is defined as the low-cost, high-volume and efficient production of personalised products, meeting all the individual requirements requested by clients in their orders (Alexander Felfernig, Hotz, Bagley, \& Tiihonen, 2014; Forza \& Salvador, 2006). The fastest way to the mass customisation of complex offerings is modular product packages and their subsequent on-demand configurations; what is also known as the configure-to-order (СТО) (Kratochvil \& Carson, 2005). The best method of customisation is the "Lego brick box" of modular products that can be configured quickly on demand. As the range of complexity and product variety increases, engineer-to-order (ETO) strategies have become more prevalent to create highly engineered complex product variants tailored to the customer's specific requirements (Wikner \& Rudberg, 2005).

However, compared to other industries, the building industry has been slow in adopting this new paradigm (Benros \& Duarte, 2009; Davison, Gibb, Austin, Goodier, \& Warner, 2006). This, according to Piroozfar and Larsen (2010), is due to the idiosyncrasies of the AEC industry, which are fundamentally different to those of other industries in eleven distinct but not mutually exclusive areas. Each of these areas is suggested to bear an impact, though to a different extent, on how modularisation, industrialisation and subsequently customisation can be strategized and implemented in the AEC industry. These differences owe their existence to the differences in the understanding of the concepts and definitions of module, modularity and modularisation between the AEC (where modularisation has traditionally been perceived as dimensional coordination) and the manufacturing industries. Azhar et al. (2013) found twelve decision-making factors which influence the decisions in favour of modular building systems over conventional construction.

\subsection{Modularisation}

A modular platform is normally used to create variants through the configuration of existing modules (Jiao, Simpson, \& Siddique, 2007; Meyer \& Lehnerd, 1997). Product modularity is considered a key enabler of mass customisation that allows for the production of modules and components in volumes. Modularisation aims to support the management of product variety and process variability by decomposing complex products and processes into smaller and simple parts (Piran et al., 2016). According to Tiihonen et al. (1996), the complexity of production is directly related to the product's degree of the modularity.

Modularisation minimises redundant efforts and non-value-adding or wasteful activities (Kratochvíl \& Carson, 2005). Wikner and Rudberg (2005) categorised the most commonly mentioned strategies of modularisation throughout the literature as ETO, make-to-order, assemble-to-order and make-to-stock. Additionally, in the context of AEC, concept-to-order is also used to describe a situation in which a customer is strongly involved at the early conceptual design stages of a building (Winch, 2003). The most important area for modularisation involves the interfaces between the components rather than the components themselves (Shafiee, 2017; Shafiee, Piroozfar, \& Hvam, 2018). 


\subsection{Modularisation strategy}

There are two different strategies for applying modularisation, namely the top-down strategy and the bottomup strategy. The top-down strategy is typically more conceptual and hence used for big projects with a higher level of complexity (Chia \& Holt, 2006; Whittington, 1996), whereas the bottom-up strategy is normally more detailed at the product level and therefore deemed more suitable for relatively smaller projects with lower levels of complexity (Kudsk, Hvam, et al., 2013). However, choosing a modularisation approach is a strategic decision based on many factors (Kudsk, Grønvold, et al., 2013), which may vary between the construction and the manufacturing industry. The top-down strategy uses general macroeconomics (input-output) and statistical data derived from industry production processes, while the bottom-up strategy breaks down the building stock into buildings, elements and materials which are linked to a detailed (upstream) process analysis (Kohler \& Hassler, 2002). The two strategies are not mutually exclusive and can be used concurrently from the opposite ends of a project in such way that the top-down strategy obtains an overview of the building to find areas for potential modularisation.

According to Forza and Salvador (2007), during the modularisation process it is necessary to determine (a) the relationships between the components, (b) the constraints and incompatibilities of the different solutions and (c) whether to use a bottom-up solution adding components one at a time or a top-down solution starting from an abstract description. This description is then put into context and upgraded in successive phases (Forza \& Salvador, 2006). Thuesen and Hvam (2013) conducted an in-depth case study based on observations and semistructured interviews to illustrate the application of bottom-up modularisation in the AEC industry. Kudsk et al. (Kudsk, Grønvold, et al., 2013) presented case study examples to illustrate the success of bottom-up modularisation. They also investigated the potential areas and real case studies in AEC regarding the application of top-down modularisation.

\subsection{Performance measurement in the AEC industry}

A performance measurement system (PMS) involves the regular collection and analysis of data about a project's input, output, efficiency and effectiveness (Sabone \& Addo-Tenkorang, 2016) through a set of metrics used to quantify the impact of different activities on the listed factors (Kohler \& Hassler, 2002; Neely, Gregory, \& Platts, 1995). Takim et al. (2003) went beyond this to assert that performance measurement is used as a systematic way to judge project performance by evaluating the inputs, outputs and the final project outcomes. Beatham et al. (2004) suggested that there are three specific types of PMS widely used in the construction industry: key performance outcomes and perception measures. Pillai et al. (2002) proposed an integrated performance index model, and the Construction Industry Task Force (Egan, 1998) developed a key performance indicator model. Although some studies have asserted that project management performance factors include time, cost, quality, safety and client satisfaction (Demirkesen \& Ozorhon, 2017), the project performance measures and indicators are widely agreed to include much more than that. Table 1 summarises the most commonly mentioned key performance measures and indicators in the literature which are considered relevant to modularisation.

Table 1. Performance Measures and Indicators in the AEC Industry

\begin{tabular}{l|l|l}
\multicolumn{2}{|c|}{ Performance measures and indicators } & \multicolumn{1}{c}{ Study (author, year) } \\
\hline 1 & $\begin{array}{l}\text { Cost/cost implications/return on investment } \\
\text { (ROI) }\end{array}$ & $\begin{array}{l}\text { (Canadian Construction Innovation Council, 2007; Cheung, Suen, \& Cheung, } \\
\text { 2004; Chew, Conejos, \& Azril, 2019; Construction Industry Institute, 2011; } \\
\text { Kohler \& Hassler, 2002; Luu, Kim, \& Huynh, 2008; Neely et al., 1995; Pillai et } \\
\text { al., 2002; Rankin, Fayek, Meade, Haas, \& Manseau, 2008; Sharifah-Akmam et } \\
\text { al., 2018; Skibniewski \& Ghosh, 2009; Wong, 2004; Xu, Chan, \& Qian, 2012) }\end{array}$ \\
\hline 2 & $\begin{array}{l}\text { Economies of scale/repetition } \\
\text { (B Hassler, 2002; Xu et al., 2012) }\end{array}$ \\
\hline 3 & $\begin{array}{l}\text { System or product compatibility and } \\
\text { interoperability }\end{array}$ & $\begin{array}{l}\text { (Beach et al., 2005; Eray, Sanchez, \& Haas, 2019; Toor \& Ogunlana, 2010; } \\
\text { Zhang, Teizer, Lee, Eastman, \& Venugopal, 2013) }\end{array}$ \\
\hline
\end{tabular}




\begin{tabular}{|c|c|c|}
\hline 4 & Interface design and tolerances & (Beach et al., 2005; Eray et al., 2019; Zhang et al., 2013) \\
\hline 5 & Multi-party and collaborative working process & $\begin{array}{l}\text { (Ahuja, Yang, \& Shankar, 2009; Beach et al., 2005; Cheung et al., 2004; } \\
\text { Constructing Excellence, 2005; Roberts \& Latorre, 2009; Toor \& Ogunlana, } \\
\text { 2010; Zhang et al., 2013) }\end{array}$ \\
\hline 6 & $\begin{array}{l}\text { Contextual conditions (including site, } \\
\text { geographical location, climate/weather, etc.) }\end{array}$ & (Xu et al., 2012; Zhang et al., 2013) \\
\hline 7 & Maintenance/repair/refurbishment & $\begin{array}{l}\text { (Chew et al., 2019; Kohler \& Hassler, 2002; Ortiz, Castells, \& Sonnemann, } \\
\text { 2009) }\end{array}$ \\
\hline 8 & $\begin{array}{l}\text { Sustainability (including environmental impact, } \\
\text { embodied and operational energy, GHG } \\
\text { emissions, etc.) }\end{array}$ & $\begin{array}{l}\text { (Chew et al., 2019; Constructing Excellence, 2005; Faludi, Lepech, \& Loisos, } \\
\text { 2012; Ortiz et al., 2009; Roberts \& Latorre, 2009; Sharifah-Akmam et al., 2018; } \\
\text { Xu et al., 2012) }\end{array}$ \\
\hline 9 & $\begin{array}{l}\text { Innovation and new technologies (including } \\
\text { Building Information Modelling (BIM), off-site } \\
\text { manufacturing (OSM), building simulation and } \\
\text { structural analysis packages, robotics, etc.) }\end{array}$ & $\begin{array}{l}\text { (Ahuja et al., 2009; Canadian Construction Innovation Council, 2007; Farr et al., } \\
\text { 2014; Rankin et al., 2008; Succar, Sher, \& Williams, 2012; Xu et al., 2012) }\end{array}$ \\
\hline 10 & Sizes and dimensions & (Godoy-shimizu et al., 2018; Ortiz et al., 2009) \\
\hline 11 & $\begin{array}{l}\text { Lifecycle/lifespan (of product, component or and } \\
\text { building) }\end{array}$ & $\begin{array}{l}\text { (Godoy-shimizu et al., 2018; Ortiz et al., 2009; Warburg, Braune, Eyerer, } \\
\text { Herrmann, \& Gallon, 2005) }\end{array}$ \\
\hline
\end{tabular}

The discussion in the section 5 highlights these factors during the analysis of the interview material, and the Discussion section investigates how these performance measurement factors might affect or be affected by the modularisation strategies applied in the case studies.

\section{Data collection}

\subsection{The case selection rationale}

The four case companies were selected for this study using the following selection criteria:

1) The company produces complex and highly-engineered building elements or components for the AEC industry.

2) The company clearly uses bottom-up or top-down modularisation strategies for at least one of their construction categories.

3) There is potential access to the management and senior experts at the company.

4) The top managers in the case company will sponsor and support all the projects.

It is also worth noting that the choice between bottom-up and/or top-down approaches does not need to be - and in case of this study was not - fait accompli, determined by what the company does deliver (i.e. the complete building solution or building sub-components). On the contrary, due to the agility, flexibility and availability of the production technologies in the AEC industry, the decision can be made as and when needed. In our study, for instance, all cases at the company deliver both building sub-components and whole building solutions, and in all the case companies chosen for this study, both modularisation strategies are applied regardless of the company's end-product. However, we chose the particular case projects based on the inclusion/exclusion criteria as explained above. Selecting more case studies from other regions in Europe or the world would have added views and perceptions constituted by other construction markets with different contextual, cultural and organisational factors. This was considered to be distracting in terms of the focus and the promise of our study. Therefore, it was decided to keep the focus on the four case companies in the North European context, which allowed us to gain an in-depth understanding of the modularisation process in each case as well as access to the companies' archival documents and records. This helped us build up a methodologically sound foundation study to help develop the later stages in other AEC industry markets across Europe and internationally. To summarise, below are the main similarities between the selected cases that provided us with the basics for qualitative comparative analysis: 
1. All the cases were selected in North Europe based on market, business and segment similarities (so that they share a common culture for the consistency and comparability of the findings).

2. The selected cases focused on residential building type. Consequently, the nature of the products and processes was the same while the products and processes had differences.

3. The selected cases all chose between bottom-up or top-down strategies for their product/process modularisation approach.

All these similarities provided us with the opportunity for a comparative analysis on the qualitative level. However, the differences between products cannot be avoided and are necessary for a qualitative comparative analysis.

\subsection{The cases description}

Table 2 summarises the background information of each case company. Company A is a Swedish AEC company active across Scandinavia as well as in the Baltic countries, northern Germany, Russia and Poland. Their prefabricated installation shaft is an example of a module, described in detail, which is included in a product that is does not primarily consist of modules. The installation shafts are made by a subsidiary of company $A$ that delivers customised installation shafts, both to internal and external customers. Instead of making the sub-components/parts/products in-situ, the products are delivered as integrated modules to the construction site, occupying only minimum space and reducing construction time significantly. Through this approach, the advantages of modularisation are exploited, the cost of developing modules is divided into smaller segments and the company can use expert knowledge in different areas.

Company B is a small Danish company which controls a networked production line that manufactures customised balconies. They used a bottom-up approach for the modularisation of building components, selected a single product and standardised its manufacture. The balconies comprise multipart products that have been standardised through the interfaces within the product. This company does not focus only on the physical product, the balcony, but on the entire process of design, fabrication, installation, customer service and support throughout the product's lifecycle.

The German platform (company C) for house building has been developed since 1994. The company realised early that the traditional AEC practice was not capable of producing low-cost houses. They needed to rethink their business and started developing their own specialised platform for housing. The platform was developed based on the market requirements. It is worth noticing that the German market is much bigger than that of Scandinavia. These houses were constructed using platforms which can cover the needs for $90 \%$ of the selected market, are designed in compliance with the German architectural traditions and are flexible enough to produce different house combinations/variations. In this project, they benefit from a top-down approach.

Company $D$ is one of the market leaders in prefabricated concrete and serves as a main contractor. They build and develop multi-family housing projects, offices, public buildings and industrial and agricultural buildings. The company has a wide range of wall elements, foundation components, floor slabs, balconies, stairs and such and offers innovative overall solutions based on a project's specific needs, requirements and preferences. The company started to modularise and develop the full house modularisation strategy and configurator circa 2012. It took them about six years to develop the whole configurator and implement all the necessary rules and regulations to the system they had started.

Table 2. Background Information of the Case Study Companies and Selected Projects

\begin{tabular}{l|c|c|c|c}
\multicolumn{2}{c|}{ Bottom-up } & \multicolumn{2}{c}{ Top-down } \\
\hline Company & $\begin{array}{c}\text { Company A } \\
\text { (medium-sized) }\end{array}$ & $\begin{array}{c}\text { Company B } \\
\text { (small-sized) }\end{array}$ & $\begin{array}{c}\text { Company C } \\
\text { (medium-sized) }\end{array}$ & $\begin{array}{c}\text { Company D } \\
\text { (medium-sized) }\end{array}$ \\
\hline
\end{tabular}




\begin{tabular}{|c|c|c|c|c|}
\hline $\begin{array}{l}\text { Projects case } \\
\text { number }\end{array}$ & Case 1 & Case 2 & Case 3 & Case 4 \\
\hline Brief background & $\begin{array}{l}\text { Swedish; active across } \\
\text { Scandinavia, the Baltic } \\
\text { countries, northern } \\
\text { Germany, Russia and } \\
\text { Poland; products delivered } \\
\text { as integrated modules to } \\
\text { the site; use of expert } \\
\text { knowledge in different } \\
\text { areas pertaining to product } \\
\text { and process. }\end{array}$ & $\begin{array}{l}\text { Danish SME; focuses } \\
\text { both on the physical } \\
\text { product and the entire } \\
\text { process of design, } \\
\text { fabrication, } \\
\text { installation, customer } \\
\text { service and support } \\
\text { throughout the } \\
\text { product's lifecycle. }\end{array}$ & $\begin{array}{l}\text { German; mostly active in } \\
\text { Germany; specialised } \\
\text { platform for housing; } \\
\text { covers the needs of } 90 \% \\
\text { of the market; complies } \\
\text { with German } \\
\text { architectural traditions } \\
\text { yet flexible enough to } \\
\text { produce different house } \\
\text { combinations and } \\
\text { variations. }\end{array}$ & $\begin{array}{l}\text { Swedish; main } \\
\text { contractor; multi-family } \\
\text { housing; leading in } \\
\text { prefabricated concrete } \\
\text { innovative } \\
\text { comprehensive solutions } \\
\text { based on a project's } \\
\text { specific needs, } \\
\text { requirements and } \\
\text { preferences. }\end{array}$ \\
\hline $\begin{array}{l}\text { Modularised } \\
\text { products }\end{array}$ & $\begin{array}{l}\text { Shafts incorporated in } \\
\text { building services mainly } \\
\text { used in Russia and Sweden } \\
\text { (modularisation and } \\
\text { configuration project) }\end{array}$ & $\begin{array}{l}\text { Complete modules for } \\
\text { balconies }\end{array}$ & $\begin{array}{l}\text { Project: affordable } \\
\text { housing for the middle } \\
\text { class (across Germany) }\end{array}$ & $\begin{array}{l}\text { Full family house } \\
\text { (modularisation and } \\
\text { configuration project) }\end{array}$ \\
\hline $\begin{array}{l}\text { Changes in processes } \\
\text { that accompanied } \\
\text { modularisation }\end{array}$ & $\begin{array}{l}\text { The sales, engineering and } \\
\text { installation processes }\end{array}$ & $\begin{array}{l}\text { The sales, engineering } \\
\text { and installation } \\
\text { processes }\end{array}$ & $\begin{array}{l}\text { The sales, engineering } \\
\text { and installation } \\
\text { processes }\end{array}$ & $\begin{array}{l}\text { The sales, engineering } \\
\text { and installation } \\
\text { processes }\end{array}$ \\
\hline Building type & Residential buildings & $\begin{array}{l}\text { Existing residential } \\
\text { buildings }\end{array}$ & $\begin{array}{l}\text { Residential, mainly } \\
\text { single-family houses, } \\
\text { small multi-story } \\
\text { buildings }\end{array}$ & $\begin{array}{l}\text { Residential buildings, } \\
\text { family houses }\end{array}$ \\
\hline $\begin{array}{l}\text { Modularisation } \\
\text { method }\end{array}$ & Bottom-up & Bottom-up & $\begin{array}{l}\text { Top-down } \\
\text { (fully modularised) }\end{array}$ & $\begin{array}{l}\text { Top-down } \\
\text { (fully modularised) }\end{array}$ \\
\hline $\begin{array}{l}\text { Individual or across- } \\
\text { the-platform } \\
\text { modularisation }\end{array}$ & $\begin{array}{l}\text { Across the platform } \\
\text { (customised shafts) }\end{array}$ & $\begin{array}{l}\text { Across the platform } \\
\text { (customised and } \\
\text { modularised product } \\
\text { and installation) }\end{array}$ & $\begin{array}{l}\text { Across the platform } \\
\text { (even installation is } \\
\text { standardised) }\end{array}$ & $\begin{array}{l}\text { Across the platform } \\
\text { (customised building) }\end{array}$ \\
\hline $\begin{array}{l}\text { Sponsors/ contact } \\
\text { person }\end{array}$ & Head of engineering & $\begin{array}{l}\text { Owner of the company, } \\
\text { СTO }\end{array}$ & $\begin{array}{l}\text { Senior } \\
\text { management/head of } \\
\text { business unit }\end{array}$ & Head of business unit \\
\hline
\end{tabular}

\subsection{Interviews}

Building upon the findings of the literature review, exploratory interview questions were designed, commensurate with the research objectives (Hollway \& Jefferson, 2000; Yin, 2009). The questions were administered through a combination of email correspondence and face-to-face interviews. Due to the exploratory nature of the research, more effort was devoted to ensuring the depth of the data inquiry, considering that the knowledge claims in this study differ from a pure statistical study (Yin, 2009). One person from each company was invited to participate in an interview with two researchers. The selection was made based on the interviewees' familiarity with modularisation, their role in the company and their involvement in the relevant processes and projects. We conducted four interviews in total, concentrating on one or multiple projects, with each lasting for around one hour. While the senior management team in each company was aware and supportive of the process, they did not participate in the interview if they did not possess the required in-depth knowledge of the project in question. Therefore, the interview participants had different positions and responsibilities within the organisational structure of their respective companies. Table 3 presents the background information of the interviewees. To triangulate and increase the validity of the collected data, two researchers conducted all the interviews and documented individual notes and recordings. 
We ensured reliable data collection by triangulating between what was documented from both the textual material and the interviews. The credibility of data analysis was also guaranteed as the interpretation of the data was analysed independently by three researchers who compared the data among themselves and agreed upon the final interpretations.

Table 3. Interviewees' Background Information

\begin{tabular}{|c|c|c|c|c|}
\hline & \multicolumn{2}{|c|}{ Bottom-up } & \multicolumn{2}{|c|}{ Top-down } \\
\hline & Company A & Company B & Company C & Company D \\
\hline Age range & $40-50$ & $30-40$ & $40-50$ & $30-40$ \\
\hline $\begin{array}{c}\text { Years of relevant experience } \\
\text { at the case company }\end{array}$ & 25 years & 3 years & 25 years & 6 years \\
\hline Current role & $\begin{array}{l}\text { Manager of concept } \\
\text { platforms (innovation) }\end{array}$ & $\begin{array}{c}\text { Researcher, } \\
\text { configuration engineer } \\
\text { (configuration systems } \\
\text { manager) }\end{array}$ & $\begin{array}{l}\text { Manager of concept } \\
\text { platforms (innovation) }\end{array}$ & Project leader \\
\hline
\end{tabular}

A first version of the questionnaire was developed based on the findings of the literature review, during a brainstorming session within the research team meant to specify the main constructs of the interviews. The questionnaire was designed to identify how best to implement the two main modularisation strategies in the AEC industry. A pilot study was carried out to test and modify the questions to ensure that the research instrument met the goal of the research design. An outline of the interview questions was provided to the interviewees prior to the interviews so they could prepare in advance.

\subsection{Documents and observation}

All available documents generated during the four modularisation projects were preliminarily collected and studied. These documents included minutes of the meetings, project management documents and other data:

1. Project description and scoping with the budget, stakeholder, resource and risk analyses.

2. Minutes of meetings and workshops discussions regarding the requirements, functions, structures and interfaces.

3. All the documents relevant to the detailed analysis of the product, detailed analysis of the processes, technical implications and modifications, customer agreements and market analysis.

4. Maintenance charts and the resources involved and change management strategies for internal and external partners.

5. Testing the modular structure of the product and the testing results including failures, additional concerns and successes.

The above-mentioned documents were not available with the same level of detail for all four case projects due to the different documentation strategies of each company. As a first step, an in-depth reading of the documents allowed us to understand the context of the projects and to build an identity card for them (scope, length, number of employees involved, number of users of the solution, etc.) as discussed in section 4.1. Moreover, this provided us with an in-depth understanding of the different processes in different companies for the modularisation process.

\subsection{Triangulation}

Additionally, three forms of triangulation were implemented in order to increase the precision of empirical research: observer triangulation, data (source) triangulation and methodological triangulation (Runeson \& Höst, 2008). First, the research team that performed the interviews and document analyses consisted of three 
researchers, allowing for observer triangulation. The interviews were conducted by one researcher only, but other researchers analysed each interview independently. Discussions were conducted with the entire research team to avoid misinterpretations. Second, the same questions were asked of all the interviewees, thus ensuring multiple response sources (data triangulation). Third, by collecting the data related to the processes in each project that supported the qualitative interview data, we considered both data sources and methodological triangulations. Finally, the interview answers were systematically verified using various documents that were produced by the multiple units of analysis.

\subsection{Data analysis}

Data analysis was performed in parallel with data collection. Qualitative data was structured into tables to provide an overview (Runeson \& Höst, 2008). First, each project was subjected to a preliminary analysis as a stand-alone entity to have an overview of the project's details based on the documents; the results were then tabulated (see section 4.1). Second, two of the researchers independently went through all the documents to find the relevant data for Table 2. Third, the interview results were analysed by examining, for each of the cases based on the performance measurements in the AEC industry as identified in the literature, the pros and cons reported by interviewees for all four projects. Lastly, the final comparison of the top-down and bottom-up modularisation based on all the collected data was tabulated (see Table 6 and 7 in section 5.5). For the sake of readability, the cross-comparative qualitative analysis was summarised in a single datasheet and identical comments were merged in order to present them in the table (section 6).

\section{Cross-case Qualitative Comparative Analysis (QCA)}

We discuss the results in three separate sections. The first section presents the steps the case companies followed to apply the modularisation process. The second section discusses the interviewees' perceptions of how some factors might affect or have been affected by the modularisation strategy applied at the case company. The third section discusses the advantages gained and the challenges faced as a result of applying modularisation.

\subsection{The steps involved in the modularisation process}

Table 4 summarises the steps the companies undertook to achieve the intended level of modularisation in each case study. The results are extracted from the answers to the following question: "Can you elaborate on the stages and processes of the work, highlighting what steps were taken before, during and after applying the strategy?"

Table 4. Steps for Applying the Modularisation Strategy in Each Case Company

\begin{tabular}{c|c|c|l} 
Steps & $\begin{array}{c}\text { Case } \\
\text { no. }\end{array}$ & Strategy & Comments \\
\hline \multirow{2}{*}{ Project scoping } & $\mathbf{1}$ & BU* $^{*}$ & $\begin{array}{l}\text { The modules were developed in a project that involved external consultants. The market } \\
\text { requirements for the modular products and the main functions were identified. }\end{array}$ \\
\cline { 2 - 5 } & $\mathbf{2}$ & BU & $\begin{array}{l}\text { In the early phases, the customer segments and products were adjusted to be more focused } \\
\text { for example, other product types and customer groups were deselected; the focus was on } \\
\text { balconies for existing apartment buildings. }\end{array}$ \\
\cline { 2 - 5 } & $\mathbf{3}$ & TD & $\begin{array}{l}\text { Everything was started from scratch. Pre-process is quite important. All the processes are on- } \\
\text { site. }\end{array}$ \\
\hline \multirow{2}{*}{$\begin{array}{c}\text { Product } \\
\text { modularisation }\end{array}$} & $\mathbf{2}$ & BU & $\begin{array}{l}\text { The modules were designed in greater detail, prototyped and tested in a factory. } \\
\text { project. }\end{array}$ \\
\cline { 2 - 5 } & BU & $\begin{array}{l}\text { The next step involved analysing the modules of balconies and product structure } \\
\text { visualisation. The mounting principles were reduced from 15 to 3. The future modules were } \\
\text { defined in two categories: standard and flexible modules, when the integration into the } \\
\text { buildings had to be somewhat flexible. }\end{array}$
\end{tabular}




\begin{tabular}{|c|c|c|c|}
\hline & 3 & TD & $\begin{array}{l}\text { It is not only the physical products that are modularised but also all the processes related to } \\
\text { the customers and all connected activities. }\end{array}$ \\
\hline & 4 & TD & $\begin{array}{l}\text { We developed frameworks to fulfil the interfaces' compatibility with the product. We started } \\
\text { to modularise different processes and products in a parallel manner to modularise the user } \\
\text { interfaces and to acquire and/or develop the right level or amount of required/necessary } \\
\text { knowledge. Simultaneously, we started to implement all the information inside the } \\
\text { configuration system and test the small deliverables as system versions by experts. }\end{array}$ \\
\hline \multirow{4}{*}{$\begin{array}{l}\text { Organisational } \\
\text { concerns }\end{array}$} & 1 & BU & $\begin{array}{l}\text { The modules were developed and tested over a } 12 \text {-month period. In the project period, the } \\
\text { requirements, functions, structures and interfaces were discussed in a series of workshops } \\
\text { involving sales, engineering, fabrication, and installation teams. }\end{array}$ \\
\hline & 2 & BU & $\begin{array}{l}\text { The processes for sales, engineering, project management and installation of the balconies } \\
\text { were developed based on the modular product structure. Sales were supported with a } \\
\text { configurator, the engineering and project management was supported with a project } \\
\text { management tool and installation was supported with instructions for the installers. }\end{array}$ \\
\hline & 3 & TD & The sole focus of the whole company was modularisation. \\
\hline & 4 & TD & $\begin{array}{l}\text { We were fully supported by the managers to implement the changes in the organisation } \\
\text { through iterative testing of the configurator. }\end{array}$ \\
\hline
\end{tabular}

** Bottom up

** Top down

Based on the backgrounds of cases 1 and 2, the modularisation process was comparatively similar as both projects focused on the details of one product (shafts in case 1 and balconies in case 2), and the relevant processes, requirements, functions, structures and interfaces were discussed based on the modular design. In both cases, projects started off with a clear scope and a discussion on the stakeholders and product details while considering the relevant processes. Moreover, cases 3 and 4 discussed the conceptual scoping of the project in a top-down process at a high level of project abstraction and how the team had to consider and connect all the products at once and determine the level of detail by discussing with the professionals at all levels of the product and production process and hierarchy. In all the selected cases except case 2, the companies manufactured both building sub-components and entire building solutions. They also used both bottom-up and top-down approaches in a range of different offerings regardless of whether they were building sub-components or complete building solutions. For the selected project cases, bottom up or top down as a modularisation strategy was the choice of the company based on the management decisions and visions.

\subsection{The impact of modularisation strategy on performance indicators in the AEC industry}

The interviewees were asked to share their perceptions of how the factors listed in Table 5 might affect or be affected by the modularisation strategy applied at their company. All the factors that complied with the key performance indicators were extracted from the previous studies listed in Table 1. Table 5 represents the results from the answers provided to the questionnaire (where $1=$ strongly disagree, $2=$ disagree, $3=$ neither agree nor disagree, $4=$ agree and $5=$ strongly agree). All the results discussed below are based on the specifications of the AEC industry discussed earlier in the literature review section. The results indicate that top-down approaches are more favoured when it comes to achieving higher scores for AEC industry performance indicators. This was unexpected, and the general expectations in the sector do not suggest this either. As there is no meaningful difference between the scores, the test itself does not bear any statistical significance. This stage was used merely as a testbed for the more detailed probing during the interviews and will be discussed in the current section and later on in the Discussion section.

Table 5. Perceptions of Factors Influencing or Affected by the Modularisation Strategy

Factor

\begin{tabular}{c|c|c|c}
\multicolumn{2}{c|}{ Bottom up } & \multicolumn{2}{c}{ Top down } \\
\hline Case 1 & Case 2 & Case 3 & Case 4 \\
\hline
\end{tabular}




\begin{tabular}{|c|c|c|c|c|c|}
\hline 1 & Cost/cost implications/return on investment (ROI) & 4 & 4 & 5 & 5 \\
\hline 2 & Economies of scale/repetition & 5 & 4 & 5 & 5 \\
\hline 3 & System or product compatibility and interoperability & 4 & 4 & 5 & 5 \\
\hline 4 & Interface design and tolerances & 4 & 5 & 5 & 5 \\
\hline 5 & Multi-party and collaborative working process & 2 & 5 & 5 & 5 \\
\hline 6 & $\begin{array}{l}\text { Contextual conditions (including site, geographical location, } \\
\text { climate/weather, etc.) }\end{array}$ & 5 & 5 & 5 & 5 \\
\hline 7 & Maintenance/repair/refurbishment & 5 & 4 & 5 & 5 \\
\hline 8 & $\begin{array}{l}\text { Sustainability (including environmental impact, embodied and operational } \\
\text { energy, GHG emissions, etc.) }\end{array}$ & 5 & $\begin{array}{l}\text { No effect } \\
(3)^{*}\end{array}$ & 5 & 5 \\
\hline 9 & $\begin{array}{l}\text { Innovation and new technologies (including BIM, OSM, building simulation } \\
\text { and structural analysis packages, robotics, etc.) }\end{array}$ & $\begin{array}{c}\text { No effect } \\
(3)^{*}\end{array}$ & 5 & 5 & 5 \\
\hline 10 & Sizes and dimensions & 3 & 4 & $\begin{array}{c}\text { No effect } \\
(3)^{*}\end{array}$ & 5 \\
\hline 11 & Lifecycle/lifespan (of product, component and/or building) & 4 & 1 & 5 & $\begin{array}{l}\text { No effect } \\
(3)^{*}\end{array}$ \\
\hline & Total Score (out of 55) & 44 & 44 & 53 & 53 \\
\hline & Percentage & $80 \%$ & $80 \%$ & $96 \%$ & $96 \%$ \\
\hline
\end{tabular}

*In some cases, the interviewees stated that some factors had no effect; these are marked as "no effect" in the table and are assigned a value of three in the scores. This is because "no effects" is equivalent to the occasions when the interviewees neither agreed nor disagreed with the statement.

\subsection{Cross-sectional comparative analysis of the modularisation strategies}

Interestingly, the overall scores for both bottom-up cases were 44 out of 55 , or $80 \%$, whereas the overall scores for the top-down cases were both at 53 out of 55 , or $96 \%$. This shows a meaningful difference in favour of topdown approaches. As mentioned, it was expected that the bottom-up strategies would be more favourable with respect to the AEC performance indicators, but this assumption was proven wrong. This could be due to several reasons. First, the Northern European construction industry's history of embracing non-site-based modern methods of construction seems to have played a role in developing such perceptions. Second, at a more individual case-based level, it seems that both companies have an established record of applying topdown strategies, with long-term benefits seeming to have started paying off. This has offset the front-end investment in longer ROI periods. In an intra-category comparison between the two top-down cases, there seem to be some discrepancies despite the equal final scores. Given that the interviewees were experts in the field and directly involved and fully aware of all project aspects in their respective companies, these discrepancies become very important in drawing a clearer picture of how, why and where they may have been rooted. This issue was probed more during the later stages of interviews and cross-checked with the company and project documents to enable us to find the reasons for such differences. While the sizes and dimensions were scored 3 (no effect) for case 3 and 5 for case 4, it was the other way around for the lifecycle or the lifespan of the product and the building. This can be attributed to two different reasons. First, case company 3 is a German company mostly active in affordable housing for the middle class in Germany, where expectedly the sizes and dimensions would not be very influential variables due to the limited variation needed to meet the market requirements. The lifecycle/lifespan of the product and the building, however, seems to be more influential, which is always the case with social and affordable housing to reduce the maintenance and running costs. Case company 4 is a Swedish main contractor, specialised in multi-family housing and leading in prefabricated concrete innovative comprehensive solutions. Due to their specialisation and system (being 
based on prefabricated concrete), the expected influential indicators are more to do size and dimension than lifecycle/lifespan issues. All other areas did not show meaningful differences in terms of the perception of the importance of the performance indicators.

\subsection{Intra-category comparative analysis of modularisation strategies}

The intra-category comparison of the two bottom-up cases shows more discrepancies and is more challenging to discuss. One of the biggest discrepancies is in the multi-partite working processes, with a score of 2 for case company 1 and a score of 5 for case company 2. It is indeed interesting to see that case company 1 , whose clients are from a wider geographical spread (probably with some language barriers), are reporting this as less of an issue. This may be due to two reasons. The more important one is that, probably, the product of case company 1 is a part of building services, therefore, although still quite crucial in terms of its technical specification and performance, it is less sensitive in terms of aesthetics and therefore less problematic in multipartite working processes where a lower number of stakeholders may be involved in the direct decision processes affecting the choice of those products. The other less likely but still possible reasons can be related to the level of product development and/or the openness/flexibility of the product system, which might be higher for case company 2's product. This is understandably linked to, and not mutually exclusive to, the first reason. The lifecycle/lifespan of the product and the building is significantly different between the two bottomup cases ( 4 for case company 1 and 1 for case company 2 ). This is due to the nature of the product in each case company. This means case company 1 , who produce a building services component, are more exposed to issues pertaining to the lifecycle/lifespan of their product, whereas this performance indicator is less of an issue with respect to case company 2's products, which are prefabricated balconies. This can also be associated with the level of wear and tear and the lifespan associated with the different building components. The other two areas of relative significant discrepancies include sustainability (with 5 for case company 1 and 3 (no effect) for case company 2) and new technologies (with 3 (no effect) for case company 1 and 5 for case company 2). With respect to sustainability, it is quite expected that a building services component or product is more sensitive in terms of its contribution to or influence on sustainability than a merely decorative component. It is, however, very interesting to see that new technologies are perceived to be more influential in delivering the balconies than they are perceived to be for the service ducts. This can be due to two different reasons. First, it might be because case company 1 had already excelled in their product and changes in the technology may not have impacted their quality of service or product. This by no means is to imply that case company 2 was not as proficient but to suggest that, because of the visually and aesthetically sensitive attributes of the product of case company 2, there may still be incremental, cosmetic or demand-oriented changes which are required; something that can heavily depend on and be facilitated by the adoption of new technologies. No significant differences were observed in other performance indicators.

The results show that top-down modularisation in the AEC industry has higher total positive effects on all the measured factors compared to the bottom-up strategy. However, the investments, complexity, size and speed of the modularised projects defined for the bottom-up strategies are much lower, simpler, smaller and faster than the top-down modularisation projects. Normally, top-down projects involve all aspects of the product and the corresponding services, which also leads to a high ROI because of the great gained benefits. The business model of case company 1 is to have a mixed approach of bottom- and top-down modularisation to use bottomup for all the products while, in parallel, having conceptual top-down modularisation for the whole building, which enables the company to reach a detailed modularised building in the long term. Aiming for this business model in case company 1 , they focus on several bottom-up modularisations for different products and then use them all in one big top-down modularisation strategy and connect them together to be able to modularise a full house. This provides a very interesting case of combining both strategies and trying to maximise the benefits of both as the portfolio of the company continues to boom and thrive. 


\subsection{The pros and cons of bottom-up and top-down strategies}

During the interview process, an elaborate explanation of the pros and cons was sought after for the different case companies. The interviewees in case companies 3 and 4 , which used a top-down strategy, mentioned that the vast modularisation across the company limited their market share and customer diversity. We, however, believe that there is a possibly more optimistic reading of the issue. Choosing to resort to a top-down strategy has made the respective companies more specialised in their offerings. This may have resulted in what appears to be a contraction the market share or diversity in the customer demographics, but, in return, it means that these companies may have to face much less competition in the market. Furthermore, it means that these companies should probably seek to contribute - through market and product R\&D, publicity, campaigning, raising awareness, education and training activities - to the inevitable change in the construction market climate. This may also mean that the company would only earn considerable benefits from a specific building type with modularised components, thus allegedly and expectedly making the company vulnerable to the loss of their share in the market when their specific modularised products are no longer suited to their customers' specific requirements or to the market requirements. To ensure that this does not affect the company in the long run and due to normal market turbulence, which may be more frequent or severe in the construction industry as opposed to other industries, R\&D and market research should find a substantial and major role in such companies to make sure that their system is always updated and in full capacity to meet the market demand, if not to be ahead of it. This probably needs to follow what is an established practice, for instance, in car manufacturing, where a product platform (with its modularised components) is designed for and has a certain service life of 4-6 years during which only minor improvements and alterations are introduced, whereas the platform will be redesigned and replaced after its service life ends, with some modules and components being carried over to the next platform generation while the previous ones is totally redesigned or replaced. What this means is that the AEC industry needs to adopt more and more the principles of 'agile production' to be able to realise the benefits top-down strategies may have to offer to be able to survive the market changes. Suffice to say that as the top-down modularisation strategy is comprehensive, the modularisation process involves the full range of products and requires a whole platform design, testing and production, which is timeconsuming and costly. Additionally, a lower system agility, at least at the beginning, might impose serious restrictions on alterations to the platform, products and/or processes compared to the bottom-up strategy. Therefore, several initial years to begin with are absolutely crucial to be able to acclimatise to the subsequent new regimes in the client demographics and market demand constructs while balancing the sheets and at the same time developing the product and platform inventory to the level at which the new system becomes more resilient and can sustain long-term changes in the market environment and client profiles.

By contrast, case companies 1 and 2 reported challenges related to the lack of integration with other modules in the building, a dependency on the IT systems and modularity and the lack of interface design modularisation. All such reported issues were expected and were already being experienced where modularisation was being adopted, partially by the established construction companies which do not want to take on the modern methods of construction fully and completely. These concerns mean a loss in profit when the orders are outside of the solution space because there is no professional expert at that stage who can estimate the costs and carry out the necessary calculations. However, as this loss is more within the profit margin, such construction companies are capable of bearing it, and rarely is it expected to have a detrimental impact on the company. Another important point worth mentioning is that, strictly speaking, such strategies are not novel and have been in practice in different parts of the world for the past 50 years. Table 6 and Table 7 summarise the participants' comments on the pros and cons of the four case companies.

Table 6. The Pros and Cons of Bottom-Up Modularisation 


\begin{tabular}{|c|c|c|}
\hline Case 1 & $\begin{array}{l}\text { - A better understanding of modularisation from different } \\
\text { product perspectives and the real benefits from the } \\
\text { modularisation. } \\
\text { - A better understanding of other technologies, such as } \\
\text { configuration. } \\
\text { - Alignment with the whole organisation and support from } \\
\text { management and a better understanding of collaboration } \\
\text { for common benefit. }\end{array}$ & $\begin{array}{l}\text { - No connections between different modules and } \\
\text { processes, for example shafts and installation } \\
\text { process are not aligned. So, we cannot get the full } \\
\text { benefits from our shafts modularisation, and } \\
\text { there are still a lot of manual works to be done. }\end{array}$ \\
\hline Case 2 & $\begin{array}{l}\text { - A very good focus on our business model and targeted } \\
\text { market. We have product and processes standardised, } \\
\text { which increases internal productivity. } \\
\text { - The huge increases in profitability during the last 10-15 } \\
\text { years. The company is ahead of the competitors, and we } \\
\text { are very fast in both processes and products. } \\
\text { - Very good communication both with the vendors and the } \\
\text { customers. That became the focus area after the } \\
\text { modularisation and simplification of the products. Now } \\
\text { we are the first in terms of customer relationships. } \\
\text { - Continuous attendance and support from the } \\
\text { management team in this process leads to constantly } \\
\text { developing the modules in terms of products and } \\
\text { processes. }\end{array}$ & $\begin{array}{l}\text { - Dependency on our modularisation IT tools, } \\
\text { such as configuration systems, which made the } \\
\text { team unaware of the specificities of the } \\
\text { products, pricing structure and processes. We } \\
\text { are struggling to make the data from the IT } \\
\text { system visible to the organisation. }\end{array}$ \\
\hline $\begin{array}{l}\text { Intra-category } \\
\text { analysis of the } \\
\text { pros and cons of } \\
\text { the bottom-up } \\
\text { strategy }\end{array}$ & $\begin{array}{l}\text { 1. The financial benefits. } \\
\text { 2. The utilisation of technology. } \\
\text { 3. Alignment with top managers. } \\
\text { 4. Clear communication with all stakeholders, including } \\
\text { vendors, customers, and the like. }\end{array}$ & $\begin{array}{l}\text { 1. Lack of connectivity (interface design } \\
\text { modularisation) to other relevant } \\
\text { products/processes. } \\
\text { 2. Lack of constant knowledge of product details } \\
\text { due to the support of modularisation. }\end{array}$ \\
\hline
\end{tabular}

Table 7. The Pros and Cons of Top-Down Modularisation

\begin{tabular}{|c|c|c|}
\hline Cases & Pros & Cons \\
\hline Case 3 & $\begin{array}{l}\text { - Offering cheap and quite-efficient services both in the sales } \\
\text { and the installation processes. } \\
\text { - Having a high quality of service. } \\
\text { - Being very fast in the (on-site, off-site) process. }\end{array}$ & $\begin{array}{l}\text { - The project outside the platforms (we are losing } \\
\text { money on the projects which do not fit into our } \\
\text { modularised platforms, for example in Western } \\
\text { Germany). }\end{array}$ \\
\hline Case 4 & $\begin{array}{l}\text { - A very high profit soon after modularisation. } \\
\text { - The project will be simplified. } \\
\text { - Customers are more satisfied and can customise their } \\
\text { houses. } \\
\text { - The output has better quality. The projects are faster. } \\
\text { - There is no waste as before. We do not sell by-chance } \\
\text { products anymore. }\end{array}$ & $\begin{array}{l}\text { - A very time-consuming (five years) project, and it } \\
\text { is very difficult to find qualified people for these } \\
\text { kinds of projects. It is hard to make people } \\
\text { collaborate and contribute. The complexity of the } \\
\text { project is high, and the workload is high. }\end{array}$ \\
\hline $\begin{array}{l}\text { Intra-category } \\
\text { analysis of the } \\
\text { pros and cons } \\
\text { of the top- } \\
\text { down strategy }\end{array}$ & $\begin{array}{l}\text { 1. Fast implementation. } \\
\text { 2. Low-cost sales and implementation. } \\
\text { 3. High-quality service. } \\
\text { 4. Satisfied customers (fast, cheap, competent). } \\
\text { 5. Decrease in waste. }\end{array}$ & $\begin{array}{l}\text { 1. The top-down modularisation process is time } \\
\text { consuming and expensive. These projects are } \\
\text { complex and a big change for organisations. } \\
\text { 2. The top-down approach dictates the limited } \\
\text { product families to be sold and limits the } \\
\text { market as well. }\end{array}$ \\
\hline
\end{tabular}

\section{Discussion}

In this section, we will summarise the cross comparative analysis presented in section 5 . Both bottom-up and top-down modularisation strategies were found to be positively influential in construction industry. However, organisations and clients alike might need to be aware of the lesson learned and the experiences accumulated when wanting to change production strategy or choose a system for their projects. The most important lessons 
learned from the bottom-up approach were reported to be the amount of concentration on only one product and missing the connection with all the other products and also sections. This conforms to what has been previously suggested by Beach et al. (2005) and Zhang et al. (2013). The most important lesson learnt from the top-down strategy was also the awareness of the organisation about their ROI targets as the project can be both lengthy and expensive before becoming profitable. Concerns have been raised by other researchers in this area before (Kohler \& Hassler, 2002; Neely et al., 1995; Sharifah-Akmam et al., 2018; Xu et al., 2012). Table 8 presents the summary of the cross QCA.

Table 8. Summary of Cross Comparative Qualitative Analysis (QCA)

\begin{tabular}{|c|c|}
\hline Strategies & Summary of lessons learned \\
\hline $\begin{array}{l}\text { Bottom- } \\
\text { up }\end{array}$ & $\begin{array}{l}\text { - The legal, installation and sub-contractor issues should be taken into consideration to achieve a satisfactory } \\
\text { level of modularisation. To elaborate more, the physical module is not the only part, and the whole process } \\
\text { (legal and installation) has to be aligned. } \\
\text { - In case of lack of connectivity and interface modularisation, the organisation should not expect to reach the } \\
\text { full benefits of modularisation. } \\
\text { - It has to be an organisational move and alignment to get the best out of this. This requires the support from } \\
\text { the managers in the organisation. } \\
\text { - The organisations have to be aware of the dependencies on modularised products and their IT support tools } \\
\text { in the future. }\end{array}$ \\
\hline Top-down & $\begin{array}{l}\text { - Top-down projects in construction industries could last long and become expensive before becoming } \\
\text { profitable. However, the interview results report a significant ROI for top-down modularisation after } \\
\text { implementation. } \\
\text { - There might be limitations for selling products outside of the defined modularised products. } \\
\text { - The top-down approach might be conceptual but comprehensive in terms of connecting different process and } \\
\text { products at a higher level of system abstraction. }\end{array}$ \\
\hline
\end{tabular}

What we found in this study as a secondary and indirect repercussion was that shifting the paradigm from conventional to modularised construction has a transitional period which, like any other 'teething period', is of paramount importance to the success of the business. This may have not been referred to before directly, especially in the construction industry. Moreover, for customers who may want to make a crucial decision about the choice of the company with a modularisation strategy or who may want to make the decision about the strategy themselves, there are factors discussed explicitly in our industry expert interviews which will have some direct or indirect short-, mid- and long-term impact on the project throughout its entire lifecycle. Some of these factors, although spotted as performance measure and indicators, were not believed to have any significant or meaningful impact on the choice of the modularisation strategy (either for a client or for a construction company). What turned out to be the case was that, although some of these issues were pointed at in the expert interviews, probably appearing to the case company as trivial from a construction professional's point of view, they may be of higher importance in the clients' opinion. These issues were related to health and safety, maintenance and upkeep, repair and refurbishment, quality and most importantly clients' satisfaction, which indeed triggered a closer interrogation of the collected data to come up with the other factors. No previous research in the relevant areas has looked into the question at hand from this point of view or flagged concerns about what was found in this study. In all of the case studies, the company chose the modularisation strategy regardless of the type or size of the end-product. Indeed, three of the case companies produce a full range of end products (materials, sub-components, components, modular units and complete building solutions) in the AEC industry.

\section{Conclusion}


This research aimed to define and compare the bottom-up and top-down modularisation strategies in the AEC industry (Figure 1). This study examined four AEC case companies, all active in Northern Europe, with substantial experience in modularisation. A QCA methodology was developed to investigate the selected case companies about their approach to the application of modularisation using multiple units of analysis and multiple data enquiry techniques. Following a critical review of the literature, first themes and areas were identified, and then a data collection and analysis strategy was decided upon and developed. The in-depth analysis of the case companies started with a secondary data analysis of factsheets and technical data pertaining to each case supplied by the participating companies. Experts with direct involvement in those project cases were interviewed to gain sufficient depth in the data querying pertaining to each case. The study discovered findings which contribute to the existing knowledge and fill the gaps related to strategies for developing and applying modularisation by construction companies and also help the construction clients to make a better and more informed choice when it comes to deciding about the selection of the construction system or method. This study employs multiple cases, multiple units of analysis and adds new dimensions for exploring top-down and bottom-up modularisation strategies in the context of the AEC industry. This will be conducted using the QCA method to systematically review and link up the use of top-down and bottom-up to performance indicators in the AEC industry, which will operationalise the research instrument of this study. The study developed some practical guidelines for companies who are considering embarking on modularisation, provided some insight for clients as to what they need to consider and set some milestones for future studies to develop a framework in this particular area of this research or within a broader scope of modularisation, platform design, automation, (pre)fabrication, standardisation, off-site manufacturing and (mass) customisation in the AEC industry.

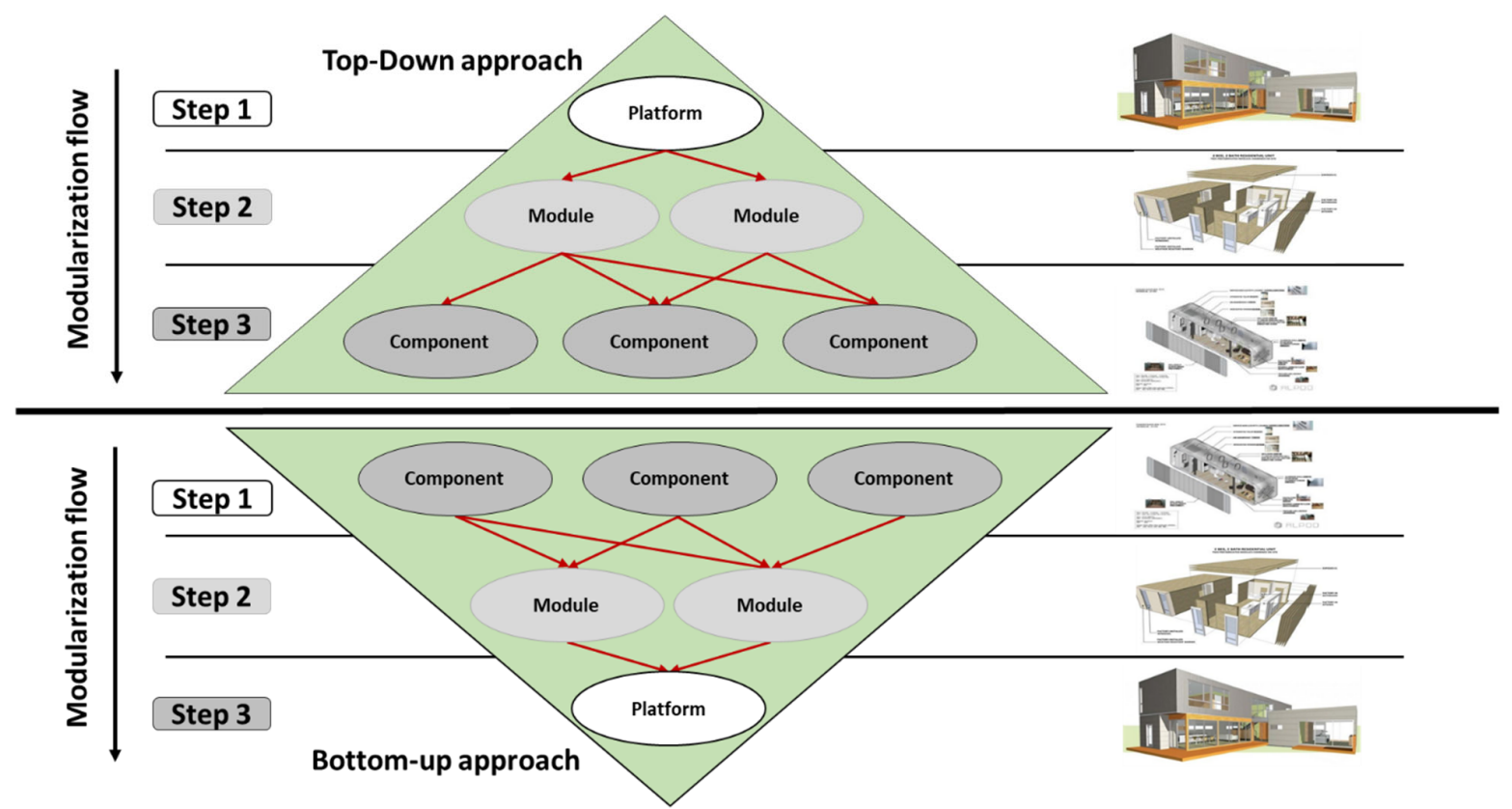

Figure 1. Top-down versus bottom-up strategies (after (Kudsk, Grønvold, et al., 2013), further developed based on the three main areas of contribution of this study.

Both strategies - bottom-up and top-down - have had significant positive and negative impacts, to differing extents, on the creativity and innovation in the design process, particularly on 'open innovation', a concept widely believed to be the next stage of development in the mass customisation paradigm. As expected, the cost implications of the two strategies - as they are in this study, and as they could be in the future due to further developments of the modularised system with advancements in IT (such as CAD and BIM) and 
manufacturing technologies (such as rapid prototyping, additive manufacturing and large-scale 3D printing) are quite diverse and subject to radical and almost unpredictable changes and shifts. Although bottom-up and top-down strategies are suited to best serve what is known, in prefabrication and industrialised AEC systems, as closed systems and open systems, respectively, modularisation cannot be suggested as a conclusive proposition. This is due to the unprecedented pace of development in the cost and affordability of, and the availability and access to, technology (in information, manufacturing and AEC/building disciplines), as well as due to recent advances in interoperability, the internet of things and the internet of places, having created an atmosphere in which no traditional boundary may hold up or is easy to realise. From a lifecycle vantage point, a top-down strategy may be more justifiable than a bottom-up strategy, or vice versa, depending on the chosen life-cycle-assessment methodology and scope (i.e. cradle-to-gate, cradle-to-grave or cradle-to-cradle), on the lifecycle inventory and on where the emphasis is intended to be placed (i.e. on embodied energy/carbon, operational energy/carbon or whole lifecycle energy/carbon).

A limitation of the study could be the geographical location, which is (limited to) the Scandinavian countries where the construction industry is more associated and familiar with industrialised systems. This, however, is not really a limitation but may provide the study with an advantage - as in those AEC contexts in Scandinavia, modularisation and platform design may have, by default, a higher/better chance of getting accepted and applied. The other limitation could be the number of cases reviewed, although this does not negatively impact the validity and reliability of the research due to its carefully adopted and devised methodology. The next limitation of the study, which could be assumed more as a future study than a limitation, is the investigation into the effects of the differences between AEC industries (especially compared to the internal sectors in the AEC industry) on modularisation approaches. Besides, the future research could discuss the differences between AEC and other industries and their influence on modularisation approaches. The other limitation of the paper is the selection of the top-down and bottom-up approaches by the company and the selection of the whole complex building for the top-down and the smaller size project for bottom-up approach.

There are potential areas for future research. This study examined some aspects of the modularised systems as exploratory research, including economies of scale, cost implications, tolerances and maintenance/repair, in-depth but rather independently. In this study, a limited number of representative case companies rated the mentioned factors and explained the benefits and challenges elaborately. All the findings and discussions from the real cases in this paper are inspiring for new in-depth studies, and the research reports the exact knowledge gained from the case companies. Therefore, future work could develop a framework based on the findings of this study to conduct a comprehensive study using a systemic strategy to investigate the correlation and interdependency of those factors. Moreover, in-depth investigations could be conducted to examine issues surrounding the manufacturing and production of both modularisation strategies, such as repetition, precision, accuracy of the moulds, formworks and jigs, installation equipment and manufacturing facilities. Further investigation into areas pertaining to time, including lead-time, time required for raw-material acquisition, manufacturing, assembly time, disassembly and recycling, quality, clients' satisfaction and post-occupancy evaluation could also shed light on the practicalities and hindrances of the wider application of modularisation strategies. A critical qualitative comparative analysis of the application of these modularisation strategies in different countries could also add significant depth, breadth and value to the existing body of knowledge in this field. Also, probably a longitudinal study can prove to be of significant value to measure and document the long-term benefits of modularisation, especially so far as maintenance, upkeep, refurbishment and repairs are concerned, for the two approaches/strategies investigated in this paper.

\section{Acknowledgement}

This work has been partially supported by the University of Brighton's Writing Retreat Fund. 


\section{References}

Ahuja, V., Yang, J., \& Shankar, R. (2009). Study of ICT adoption for building project management in the Indian construction industry. Automation in Construction, 18(4), 415-423. https://doi.org/10.1016/j.autcon.2008.10.009

Azhar, S., Lukkad, M. Y., \& Ahmad, I. (2013). An investigation of critical factors and constraints for selecting modular construction overconventional stick-built technique. International Journal of Construction Education and Research, 9(3), 203-225. https://doi.org/10.1080/15578771.2012.723115

Baldwin, C. Y., \& Clark, K. B. (2000). Design rules: The power of modularity (Vol. 1). New York, NY: Routledge: MIT press.

Beach, R., Webster, M., \& Campbell, K. M. (2005). An evaluation of partnership development in the construction industry. International Journal of Project Management, 23(8), 611-621. https://doi.org/10.1016/j.ijproman.2005.04.001

Bekdik, B., Pörzgen, J., Bull, S. S., \& Thuesen, C. (2018). Modularising design processes of façades in Denmark: re-exploring the use of design structure matrix. Architectural Engineering and Design Management, 14(12), 95-108. https://doi.org/10.1080/17452007.2017.1360760

Benros, D., \& Duarte, J. P. (2009). An integrated system for providing mass customized housing. Automation in Construction, 18(3), 310-320. https://doi.org/10.1016/j.autcon.2008.09.006

Canadian Construction Innovation Council. (2007). Construction innovation (Vol. 12). Ottawa, Ontario.

Cheung, S. O., Suen, H. C. H., \& Cheung, K. K. W. (2004). PPMS: A Web-based construction Project Performance Monitoring System. Automation in Construction, 13(3), 361-376. https://doi.org/10.1016/j.autcon.2003.12.001

Chew, M. Y. L., Conejos, S., \& Azril, F. H. Bin. (2019). Design for maintainability of high-rise vertical green facades. Building Research and Information, 47(4), 453-467. https://doi.org/10.1080/09613218.2018.1440716

Chia, R., \& Holt, R. (2006). Strategy as practical coping: A Heideggerian perspective. Organization Studies, 27(5), 344-345. https://doi.org/10.1177/0170840606064102

Choo, H. J., Hammond, J., Tommelein, I. D., Austin, S. A., \& Ballard, G. (2004). DePlan: A tool for integrated design management. Automation in Construction, 13(3), 313-326. https://doi.org/10.1016/j.autcon.2003.09.012

Cigolini, R., \& Castellano, A. (2002). Using modularization to manage construction of onshore process plants: A theoretical approach and a case study. Project Management Journal, 33(2), 29-40. https://doi.org/10.1177/875697280203300205

Constructing Excellence. (2005). Environment KPIs methods of measurement. London, UK.

Construction Industry Institute. (2011). Benchmarking and metrics. Austin, Texas.

Davison, N., Gibb, A. G. F., Austin, S. A., Goodier, C. I., \& Warner, P. (2006). The Multispace adaptable building concept and its extension into mass customisation. In International Conference On Adaptable Building Structures. Eindhoven, The Netherlands: CIB.

Demirkesen, S., \& Ozorhon, B. (2017). Measuring project management performance: Case of construction 
industry. Engineering Management $\quad$ Journal, $258-277$. https://doi.org/10.1080/10429247.2017.1380579

Egan, J. (1998). Rethinking construction: The report of the construction task force. London, UK: HMSO. Retrieved from http://constructingexcellence.org.uk/wpcontent/uploads/2014/10/rethinking_construction_report.pdf

Eisenhardt, K. (1989). Building theories from case study. Academy of Management Review, 14(4), 532-550.

Eray, E., Sanchez, B., \& Haas, C. (2019). Usage of interface management system in adaptive reuse of buildings. Buildings, 9(5), 105. https://doi.org/10.3390/buildings9050105

Faludi, J., Lepech, M. D., \& Loisos, G. (2012). Using life cycle assessment methods to guide architectural decision-making for sustainable prefabricated modular buildings. Journal of Green Building, 7(3), 151170. https://doi.org/10.3992/jgb.7.3.151

Farr, E. R. P., Piroozfar, P. A. E., \& Robinson, D. (2014). BIM as a generic configurator for facilitation of customisation in the AEC industry. Automation in Construction, 45, 119-125. https://doi.org/10.1016/j.autcon.2014.05.012

Felfernig, Alexander, Hotz, L., Bagley, C., \& Tiihonen, J. (2014). Knowledge-Based Configuration From Research to Business Cases. Newnes: Morgan Kaufman. https://doi.org/10.1016/B978-0-12-415817-7.00029-3

Felfernig, Alexander, Reiterer, S., Reinfrank, F., Ninaus, G., \& Jeran, M. (2014). Conflict Detection and Diagnosis in Configuration. In A. Felfernig, L. Hotz, C. Bagley, \& J. Tiihonen (Eds.), Knowledge-based configuration: From research to business cases (pp. 73-87). Morgan Kaufman, Newnes. https://doi.org/10.1016/B9780-12-415817-7.00029-3

Finifter, A. W. (1993). Political science: The state of the discipline II. Amer Political Science Assn.

Forza, C., \& Salvador, F. (2006). Product information management for mass customization: Connecting customer, front-office and back-office for fast and efficient customization. New York, NY: Palgrave Macmillan.

Godoy-shimizu, D., Steadman, P., Hamilton, I., Donn, M., Evans, S., Moreno, G., \& Shayesteh, H. (2018). Energy use and height in office buildings. Building Research \& Information, 46(8), 1-19. https://doi.org/10.1080/09613218.2018.1479927

Goulding, J., \& Arif, M. (2013). Offsite production and manufacturing - research roadmap report. In International council for research and innovation in building and construction (CIB) (p. 43). Publication 372.

Gummesson, E. (2000). Qualitative methods in management research. California, USA: Sage publications, Inc.

Haas, C. T., \& Fagerlund, W. R. (2002). Preliminary research on prefabrication, pre-assembly, modularization and off-site fabrication in construction. Construction Industry Institute, Department of Civil Engineering, University of Texas at Austin.

Hartmann, T., Meerveld, H. Van, Vossebeld, N., \& Adriaanse, A. (2012). Automation in construction aligning building information model tools and construction management methods. Automation in Construction, 22, 605-613. https://doi.org/10.1016/j.autcon.2011.12.011

Hollway, W., \& Jefferson, T. (2000). Doing qualitative research differently: Free association, narrative and the 
interview method. London, UK: Routledge.

Hvam, L., Mortensen, N. H., \& Riis, J. (2008). Product customization. Berlin Heidelberg, Germany: SpringerVerlag. https://doi.org/10.1007/978-3-540-71449-1

Jagarajan, R., Abdullah Mohd Asmoni, M. N., Mohammed, A. H., Jaafar, M. N., Lee Yim Mei, J., \& Baba, M. (2017). Green retrofitting - A review of current status, implementations and challenges. Renewable and Sustainable Energy Reviews, 67, 1360-1368. https://doi.org/10.1016/j.rser.2016.09.091

Jiao, J., Simpson, T. W., \& Siddique, Z. (2007). Product family design and platform-based product development: A state-of-the-art review. Journal of Intelligent Manufacturing, 18(1), 5-29. https://doi.org/10.1007/s10845-007-0003-2

Karlosson, C. (2016). Research methods for operations management. London: Routledge Taylor \& Francis Group.

Kibert, C. J. (2007). The next generation of sustainable construction. Building Research and Information, 35(6), 595-601. https://doi.org/10.1080/09613210701467040

Kohler, N., \& Hassler, U. (2002). The building stock as a research object. Building Research and Information, 30(4), 226-236. https://doi.org/10.1080/09613210110102238

Kratochvíl, M., \& Carson, C. (2005). Growing modular: Mass customization of complex products, services and software. hampton Hill, UK: Springer Science \& Business Media. https://doi.org/10.1007/b139063

Kudsk, A., Grønvold, M. O. B., Olsen, M. H., Hvam, L., \& Thuesen, C. (2013). Stepwise modularization in the construction industry using a bottom-up approach. The Open Construction and Building Technology Journal, 7, 99-107. https://doi.org/10.2174/1874836801307010099

Kudsk, A., Hvam, L., Thuesen, C., Grønvold, M. O., \& Olsen, M. H. (2013). Modularization in the construction industry using a top-down approach. The Open Construction and Building Technology Journal, 7(1), 99107. https://doi.org/10.2174/1874836801307010088

Lachimpadi, S. K., Pereira, J. J., Taha, M. R., \& Mokhtar, M. (2012). Construction waste minimisation comparing conventional and precast construction (Mixed System and IBS) methods in high-rise buildings: A Malaysia case study. Resources, Conservation and Recycling, 68, 96-103. https://doi.org/10.1016/j.resconrec.2012.08.011

Langlois, R. . (2002). Modularity in technology and organization. Journal of Economic Behavior and Organization, 49, 19-37. https://doi.org/10.1016/S0167-2681(02)00056-2

Lawson, M., Ogden, R., \& Goodier, C. (2014). Design in Modular Construction. CRC Press. London, UK: CRC Press. https://doi.org/10.1080/10464883.2017.1260969

Luu, V. T., Kim, S.-Y., \& Huynh, T.-A. (2008). Improving project management performance of large contractors using benchmarking approach. International Journal of Project Management, 26(7), 758-769.

Mäkipää, M., Ahoniemi, L., Mertanen, M., Sievänen, M., Peltonen, L., \& Ruohonen, M. (2010). The state of the art of mass customization practices in Finnish technology industries: Results from a multiple-case study. In F. T. Piller \& M. M. Tseng (Eds.), Handbook of research in mass customization and personalization (pp. 943-964). World Scientific.

Mancini, M. (2014). Advances in plant modularisation. From the state of art to emerging challenges. Milano, 
Italy: Italian National Assocation of Industrial Plant Engineering.

McCutcheon, D. M., \& Meredith, J. R. (1993). Conducting case study research in operations management. Journal of Operations Management, 11(3), 239-256. https://doi.org/10.1016/0272-6963(93)90002-7

Meyer, M. H., \& Lehnerd, A. P. (1997). The power of product platforms: Building value and cost leadership. New York: Free Press. New York, USA: Free Press.

Neely, A., Gregory, M., \& Platts, K. (1995). Performance measurement system design: A literature review and research agenda. International Journal of Operations \& Production Management, 15(4), 80-116. https://doi.org/http://dx.doi.org/10.1108/01443579510083622

Oakley, A. (1999). People's way of knowing: Gender and methodology. In S. Hood, B. Mayall, \& S. Oliver (Eds.), Critical Issues in Social Research (pp. 154-177). Buckingham: Open University Press.

Ortiz, O., Castells, F., \& Sonnemann, G. (2009). Sustainability in the construction industry: A review of recent developments based on LCA. Construction and Building Materials, 23(1), 28-39. https://doi.org/10.1016/j.conbuildmat.2007.11.012

Pickvance, C. (2005). The four varieties of comparative analysis: The case of environmental regulation. In Conference on Small and large-N comparative solutions, University of Sussex (pp. 22-23). University of Sussex. Retrieved from http://eprints.ncrm.ac.uk/57/1/chrispickvance.pdf

Pillai, A. S., Joshi, A., \& Rao, K. S. (2002). Performance measurement of R\&D projects in a multi-project concurrent engineering environment. International Journal of Project Management, 20, 165-177.

Pine, B. J. (1993). Mass customization: The new frontier in business competition. Harvard Business Review Press.

Piran, F. A. S., Lacerda, D. P., Antunes, J. A. V., Viero, C. F., \& Dresch, A. (2016). Modularization strategy: Analysis of published articles on production and operations management (1999 to 2013). International Journal of Advanced Manufacturing Technology, 86(1-4), 507-519. https://doi.org/10.1007/s00170-015-8221-9

Piroozfar, A. E., \& Larsen, O. P. (2010). Customizing building envelopes: retrospects and prospects of customization in the building industry. In F. T. Piller \& M. M. Tseng (Eds.), Handbook of research in mass customization and personalization (pp. 869-891). World Scientific.

Rankin, J., Fayek, A. R., Meade, G., Haas, C., \& Manseau, A. (2008). Initial metrics and pilot program results for measuring the performance of the Canadian construction industry. Canadian Journal of Civil Engineering, 35(9), 894-907.

Roberts, M., \& Latorre, V. (2009). KPIs in the UK's construction industry: Using system dynamics to understand underachievement. Revista de La Construcción, 8(1), 69-82.

Runeson, P., \& Höst, M. (2008). Guidelines for conducting and reporting case study research in software engineering. Empirical Software Engineering, 14(2), 131-164. https://doi.org/10.1007/s10664-008-91028

Sabone, M., \& Addo-Tenkorang, R. (2016). Benchmarking performance measurement systems in Botswana's construction sector. Journal of Construction Project Management and Innovation, 6(March 2017), 14891502.

Sawhney, A., \& Maheswari, J. U. (2013). Design coordination using cloud-based smart building element models. International Journal of Computer Information Systems and Industrial Management Applications, 5, 445- 
453. Retrieved from http://mirlabs.net/ijcisim/regular_papers_2013/Paper120.pdf

Shafiee, S. (2017). Conceptual Modelling for Product Configuration Systems. Technical University of Denmark, Denmark.

Shafiee, S., Piroozfar, P., \& Hvam, L. (2018). Product Modularization: Case Studies From Construction Industries. In 8th International Conference on Mass Customization and Personalization. Novi Sad, Serbia.

Sharifah-Akmam, S. Z., Gajendran, T., Skitmore, M., \& Brewer, G. (2018). Key factors influencing the decision to adopt industrialised building systems technology in the Malaysian construction industry: An interproject perspective. Architectural Engineering and Design Management, 14(1-2), 27-45. https://doi.org/10.1080/17452007.2017.1298512

Singh, M. M., Sawhney, A., \& Borrmann, A. (2015). Modular coordination and BIM: Development of rule-based smart building components. Procedia Engineering, 123, 519-527. https://doi.org/10.1016/j.proeng.2015.10.104

Skibniewski, M. J., \& Ghosh, S. (2009). Determination of key performance indicators with enterprise resource planning systems in engineering construction firms. Journal of Construction Engineering and Management, 135(10), 965-978.

Smith, R. E. (2011). Prefab architecture: A guide to modular design and construction. Hoboken, NJ: John Wiley \& Sons.

Succar, B., Sher, W., \& Williams, A. (2012). Measuring BIM performance: Five metrics. Architectural Engineering and Design Management, 8(2), 120-142. https://doi.org/10.1080/17452007.2012.659506

Sun, R., \& Zhang, X. (2004). Top-down versus bottom-up learning in cognitive skill acquisition. Cognitive Systems Research, 5(1), 63-89. https://doi.org/10.1016/j.cogsys.2003.07.001

Takim, R., Akintoye, A., \& Kelly, J. (2003). Performance measurement systems in construction. In 19th Annual ARCOM Conference (Vol. 1, pp. 423-32). University of Brighton: Association of Researchers in Construction Management.

Tatum, C. B., Vanegas, J. A., \& Williams, J. M. (1987). Constructability improvement using prefabrication, preassembly, and modularization. Austin, TX: Construction Industry Institute.

Thuesen, C., \& Hvam, L. (2013). Rethinking the business model in construction by the se of off-site system deliverance: Case of the shaft project. Journal of Architectural Engineering, 19(4), 279-287. https://doi.org/10.1061/(ASCE)AE.1943-5568.0000095

Tiihonen, J., Soininen, T., Männistö, T., \& Sulonen, R. (1996). State-of-the-practice in product configuration A survey of 10 cases in the Finnish industry. In T. Tomyiama, M. Mantyla, \& S. Finger (Eds.), Knowledgeintensive CAD, Proceedings of the First IFIP WG 5.2 Workshop, Finland (Vol. 1, pp. 95-114). Chapman \& Hall, London: Springer. https://doi.org/10.1007/978-0-387-34930-5_7

Tilly, C. (1984). Big structures, large processes, huge comparisons. New York, NY: Russell Sage Foundation.

Toor, S. u R., \& Ogunlana, S. O. (2010). Beyond the "iron triangle": Stakeholder perception of key performance indicators (KPIs) for large-scale public sector development projects. International Journal of Project Management, 28(3), 228-236. https://doi.org/10.1016/j.ijproman.2009.05.005

Tsang, E. W. K. (2013). Case study methodology: Causal explanation, contextualization, and theorizing. Journal 
of International Management, 19(2), 195-202. https://doi.org/10.1016/j.intman.2012.08.004

Van de Ven, A. H. (1989). Nothing is quite so practical as a good theory. Academy of Management Review, 14(4), 486-489. https://doi.org/10.5465/AMR.1989.4308370

Vernikos, V. K., Goodier, C. I., Nelson, R., \& Robery, P. C. (2013). Implementing an offsite construction strategy: A UK contracting organisation case study. In S. D. Smith \& D. D. Ahiaga-Dagbui (Eds.), 29th Annual ARCOM Conference (pp. 667-677). Association of Researchers in Construction Management (ARCOM).

Warburg, N., Braune, A., Eyerer, P., Herrmann, C., \& Gallon, N. (2005). Environmental indicators for ICT products. In Proceedings of the 2005 IEEE International Symposium on Electronics and the Environment, 2005. (pp. 226-230). IEEE. https://doi.org/10.1109/isee.2005.1437030

Whittington, R. (1996). Strategy as practice. Strategy as Practice, 29(5), 731-735.

Wikner, J., \& Rudberg, M. (2005). Integrating production and engineering perspectives on the customer order decoupling point. International Journal of Operations \& Production Management, 25(7), 623. https://doi.org/10.1108/01443570510605072

Winch, G. M. (2003). Models of manufacturing and the construction process: The genesis of re-engineering construction. Building Research and Information, 31(2), 107-118. https://doi.org/10.1080/09613210301995

Wong, C. H. (2004). Contractor performance prediction model for the United Kingdom construction contractor: Study of logistic regression approach. Journal of Construction Engineering and Management, 130(5), 691698.

Xu, P. P., Chan, E. H. W., \& Qian, Q. K. (2012). Key performance indicators (KPI) for the sustainability of building energy efficiency retrofit (BEER) in hotel buildings in China. Facilities, 30(9), 432-448. https://doi.org/10.1108/02632771211235242

Yin, R. K. (2009). Case study research: Design and methods (applied social research methods). Thousand Oaks, CA: Sage.

Zhang, S., Teizer, J., Lee, J. K., Eastman, C. M., \& Venugopal, M. (2013). Building information modeling (BIM) and safety: Automatic safety checking of construction models and schedules. Automation in Construction, 29, 183-195. https://doi.org/10.1016/j.autcon.2012.05.006 